\title{
Generation of Thymine Triplet State by Through-Bond Energy Transfer
}

\author{
Paula Miro, Miguel Gomez-Mendoza, Germán Sastre, M. Consuelo Cuquerella, Miguel A. Miranda* \\ and M. Luisa Marin ${ }^{*[a]}$
}

\begin{abstract}
Benzophenone (BP) and drugs containing the BP chromophore, such as the non-steroidal antiinflammatory drug ketoprofen, have been widely reported as DNA photosensitizers via triplet-triplet energy transfer (TTET). In the present work, direct spectroscopic fingerprint for the formation of ${ }^{3} \mathrm{Thy} \mathrm{H}^{*}$ through-bond (TB) TTET from ${ }^{3} \mathrm{BP}^{*}$ is provided. This goal has been achieved in two new systems that have been designed and synthesized with one BP and one Thy covalently linked to both ends of the rigid skeleton of the natural bile acids cholic or lithocholic acid. The results shown here prove that it is possible to achieve triplet energy transfer to a Thy unit even when the photosensitizer is at a long (non-bonding) distance.
\end{abstract}

\section{Introduction}

The ultraviolet (UV) fraction of solar radiation incident on the Earth surface has demonstrated to be harmful for living organisms, since it can cause photochemical alterations of the DNA structure. ${ }^{[1]}$ Specifically, UVB is absorbed by the nucleobases themselves, causing direct photoreactions between adjacent thymine (Thy) and/or cytosine (Cyt) units. This gives mainly rise to cyclobutane pyrimidine dimers (CPDs), which have been reported among the most mutagenic lesions. ${ }^{[2]}$ Thus, formation of CPDs (Thy<>Thy, Thy<>Cyt or Cyt<>Cyt) starts with the absorption of UVB light by one pyrimidine followed by a [2+2] photochemical cycloaddition between the C5-C6 double bonds of the excited Thy or Cyt and another pyrimidine in its ground state, leading to the final photolesion. Fortunately, evolution is responsible for the intrinsic photostability properties of the nucleobases, since they exhibit an extremely short-lived singlet excited state and a very low ISC quantum yield. ${ }^{[3]}$

Although the UVA fraction of solar light is not efficiently absorbed by the nucleobases, UVA-absorbing endogenous or exogenous photosensitizers can mediate additional photochemical disorders. For instance, photosensitized formation of CPDs has been reported; ${ }^{[4]}$ however, questions such as how does triplet excitation travel within DNA, or which is the maximum distance for efficient triplet energy transfer until reaching a Thy (the lowest triplet energy nucleobase) are important issues that have only recently attracted attention. ${ }^{[5]}$ By contrast, related processes, such as hole ${ }^{[6]}$ or excess electron transfer ${ }^{[7]}$ along DNA, have been thoroughly investigated.

Benzophenone (BP) and drugs containing the BP chromophore, such as the non-steroidal antiinflammatory drug $(S)$-ketoprofen $(\mathrm{KP})$, have been widely reported as DNA photosensitizers. ${ }^{[8]}$ By

[a] Dr. M. Luisa Marin, Prof. Miguel A. Miranda Instituto de Tecnología Química, Universitat Politècnica de València-Consejo Superior de Investigaciones Científicas, Avenida de los Naranjos s/n, 46022 Valencia, Spain marmarin@qim.upv.es; mmiranda@qim.upv.es

Supporting information for this article is given via a link at the end of the document. contrast with CPDs formation by direct UVB-light absorption, which takes predominantly place from the singlet excited state,,$^{\left[{ }^{9]}\right.}$ the KP-photosensitized generation of CPDs between two monomer Thy nucleobases is assumed to occur by triplet-triplet energy transfer (TTET) from KP followed by [2+2] cycloaddition. ${ }^{[4}$, ${ }^{8 a]}$ Although the reported triplet energies $\left(69 \mathrm{kcal} / \mathrm{mol}^{[10]}\right.$ and 74 $\left.\mathrm{kcal} / \mathrm{mol}^{[8 \mathrm{a}]}\right)$ point to a slightly disfavored process in solution, ${ }^{[11]}$ there is indeed a remarkable overlap of the phosphorescence spectra (see Fig. S1), which differ mainly in the higher energy edge and in the structureless shape of the nucleobase. Furthermore, the unambiguous detection of Cyt<>Cyt in BPphotosensitized DNA has recently been reported, despite the triplet state energy of $\mathrm{Cyt}^{\left[{ }^{[12]}\right.}$ which is somewhat higher than that of Thy.

A mechanistic explanation for the interaction between ${ }^{3} \mathrm{BP}^{*}$ and Thy is outlined in Scheme 1. Thus, reaction between ${ }^{3} \mathrm{BP}^{*}$ and Thy could give rise directly to ${ }^{3}$ Thy $^{*}$ by TTET or to the exciplex ${ }^{3}[\mathrm{BP} \ldots \text {...Thy }]^{*}$, which subsequently would evolve to ${ }^{3} \mathrm{Thy}^{*}$ or to the oxetane $\mathrm{BP}<\mathrm{O}^{\circ}$ Thy. ${ }^{[13]}$ Surprisingly, direct evidence supporting formation of the key species ${ }^{3}$ Thy* upon BP photosensitization has never been provided. The main reasons to explain this fact are: i) the TTET process has to compete with the more efficient Paternò-Büchi reaction between the carbonyl moiety of ${ }^{3} \mathrm{BP}^{*}\left(\mathrm{n} \pi^{*}\right.$ nature) and the $\mathrm{C} 5-\mathrm{C} 6$ olefinic region of Thy; ${ }^{[14]}$ ii) the very low absorption coefficient of the Thy T-T absorption band, centred at $370 \mathrm{~nm}^{[13 \mathrm{a}, 15]}$ or iii) the spectral overlap between ${ }^{3} \mathrm{BP}^{*}$ (with two bands peaking at 320 and $530 \mathrm{~nm}$ ) and ${ }^{3}$ Thy (a broad band centered at $370 \mathrm{~nm}$ ). Therefore, until now, only with more energetic triplet ketones such as acetone, acetophenone, propiophenone and 1-indanone, it has been possible to prove sensitization of ${ }^{3}$ Thy ${ }^{*}$ by TTET. ${ }^{[13 a]}$

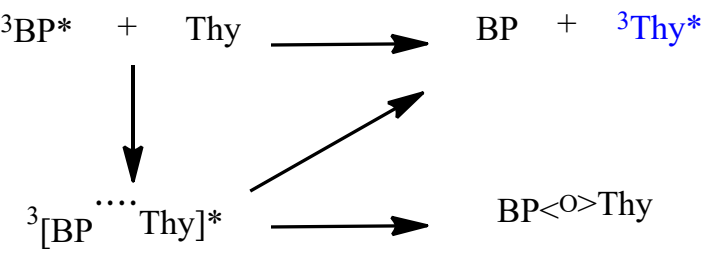

Scheme 1. Simplified mechanisms to explain interaction between triplet benzophenone and thymine

In order to provide direct evidence for the BP-photosensitized formation of ${ }^{3}$ Thy* it would be necessary to block formation of oxetanes, which constitutes the main deactivation pathway of ${ }^{3} \mathrm{BP}^{*}$. We have recently shown that the thermodynamically favored TTET from ${ }^{3} \mathrm{BP}^{*}$ to naphthalene (Npt) or biphenyl (Bip) can efficiently happen through-bond (TB) in intramolecular systems in which the two chromophores are separated by a rigid hydrocarbon bridge (interchromophore distance in the range of 15-20 A). ${ }^{[16]}$ In fact, formation of ${ }^{3} \mathrm{Npt}^{*}$ or ${ }^{3} \mathrm{Bip}^{*}$ upon selective excitation of BP has been demonstrated by laser flash photolysis (LFP) in dyads in which BP/Npt or BP/Bip are covalently attached to the $3 \alpha$ - position (donor) and lateral chain (acceptor) of lithocholic acid (LA). ${ }^{[16]}$ However, no examples of TB-TTET in 
systems where the accepting unit is a nucleobase have been reported to date.

With this background, the aim of the present work is to obtain spectroscopic evidence for the formation of ${ }^{3}$ Thy ${ }^{*}$ by TB-TTET from ${ }^{3} \mathrm{BP}^{*}$. To achieve this goal two new systems have been designed and synthesized, in which one BP and one Thy are covalently linked to both ends of the rigid skeleton of the natural bile acids, cholic and lithocholic acids (CA and LA, respectively). This way, the formation of oxetanes is prevented due to the long (non-bonding) distance between the chromophores imposed by the bile acid scaffold, as a consequence, the predominance of TTET is secured. In addition, the use of LA, which presents no secondary alcohol moieties, would minimize alternative reactions such as $\mathrm{H}$-abstraction by ${ }^{3} \mathrm{BP}^{*}$. The obtained results could shed light on triplet excitation travelling along DNA until targeting a Thy unit.

\section{Results and Discussion}

The synthetic strategies developed to prepare the target compound $\mathbf{2}$ in a first instance, and $\mathbf{5}$ afterwards in addition to the corresponding controls $\mathbf{1}$ and $\mathbf{6}$ are outlined in Scheme 2. Briefly, $\mathrm{CA}$ was esterified using reduced KP to give compound 1 , which was used as a control. Subsequent esterification of the most reactive $\mathrm{C}-3$ position of $\mathbf{1}$, using thymine-1-acetic acid (Thy$\mathrm{CH}_{2} \mathrm{CO}_{2} \mathrm{H}$ ), gave dyad 2. In parallel, LA was reduced with $\mathrm{LiAlH}_{4}$, to give the corresponding primary alcohol, 3. Subsequent derivatization of the lateral chain with $\mathrm{ThyCH}_{2} \mathrm{CO}_{2} \mathrm{H}$ yielded 4 . Then, the secondary hydroxyl group of $\mathbf{4}$ was reacted with $\mathrm{KP}$ to give 5. In parallel, $\mathbf{6}$ was obtained upon esterification of the $3 a-$ position of LA with KP.

Next, the transient absorption spectrum of $\mathbf{2}$ was recorded upon LFP excitation of the BP at $355 \mathrm{~nm}$, and the typical bands of ${ }^{3} \mathrm{BP}^{*}$ $\left(\lambda_{\max }\right.$ ca. 320 and $530 \mathrm{~nm}$ ) were observed at first sight (Figure 1, top). Likewise, 1 was subjected to excitation of the BP at $355 \mathrm{~nm}$, and again the characteristic bands of ${ }^{3} \mathrm{BP}^{*}$ were observed (Figure 1 , middle). When the two spectra were compared, clear differences were noticed in the region between 350 and $400 \mathrm{~nm}$, which were consistent with the presence of ${ }^{3} \mathrm{Thy}$, that would result from TB-TTET (Figure 1, bottom). ${ }^{[13 a]}$ Although we attempted to obtain the ${ }^{3}$ Thy $^{*}$ spectrum allowing for decay of the overlapped ${ }^{3} \mathrm{BP}^{*}$, after ca $2 \mu$ s only very weak traces remained. This is probably related to the fact that ${ }^{3} \mathrm{Thy}^{*}$, when bound to the bile acid skeleton, in $\mathrm{CH}_{2} \mathrm{Cl}_{2}$, is shorter-lived than expected for free ${ }^{3}$ Thy ${ }^{*}$ in water.

To get a more clear piece of evidence for the formation of ${ }^{3} \mathrm{Thy}^{*}$, due to the spectral overlap and to the low molar absorption coefficient of ${ }^{3} \mathrm{Thy}^{*}$, difference spectra were obtained. Thus, subtraction of the spectrum obtained for $\mathbf{1}$ from the one of 2, both taken $0.5 \mu$ s after the laser pulse, resulted in a spectrum (Figure 2 , top), which was consistent with the one already reported for ${ }^{3}$ Thy* obtained by TTET from the more energetic triplet of acetone. ${ }^{[13 a]}$

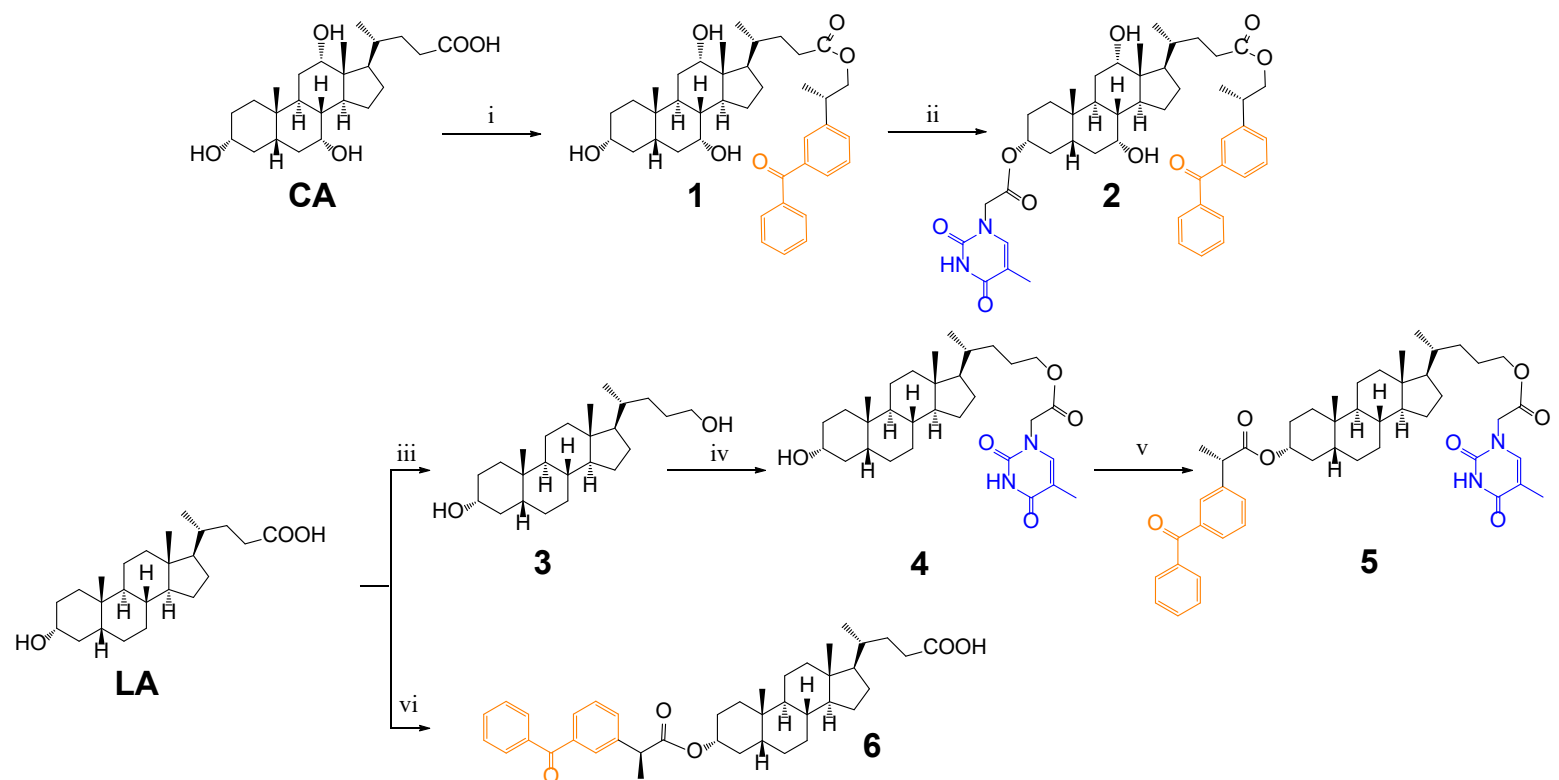

Scheme 2. Synthetic strategy to prepare $\mathrm{CA}$ and $\mathrm{LA}$ derivatives incorporating Thy and/or BP. Reagents and conditions: (i) KP-OH, 4-DMAP, EDC, $\mathrm{C}_{5} \mathrm{H}_{5} \mathrm{~N}$ (50\%); (ii) Thy- $\mathrm{CH}_{2} \mathrm{CO}_{2} \mathrm{H}$, 4-DMAP, EDC, DMF (63\%); (iii) LiAlH 4 , THF, (88\%); (iv) ThyCH $\mathrm{CH}_{2} \mathrm{CO}_{2} \mathrm{H}, \mathrm{TBTU}, \mathrm{DIEA}, \mathrm{DMF},(36 \%)$; (v) KP, TBTU, DIEA, DMF, (73\%); (iv) $\mathrm{KP}, \mathrm{DCC}, 4-\mathrm{DMAP}, \mathrm{CH}_{2} \mathrm{Cl}_{2}(70 \%)$. 

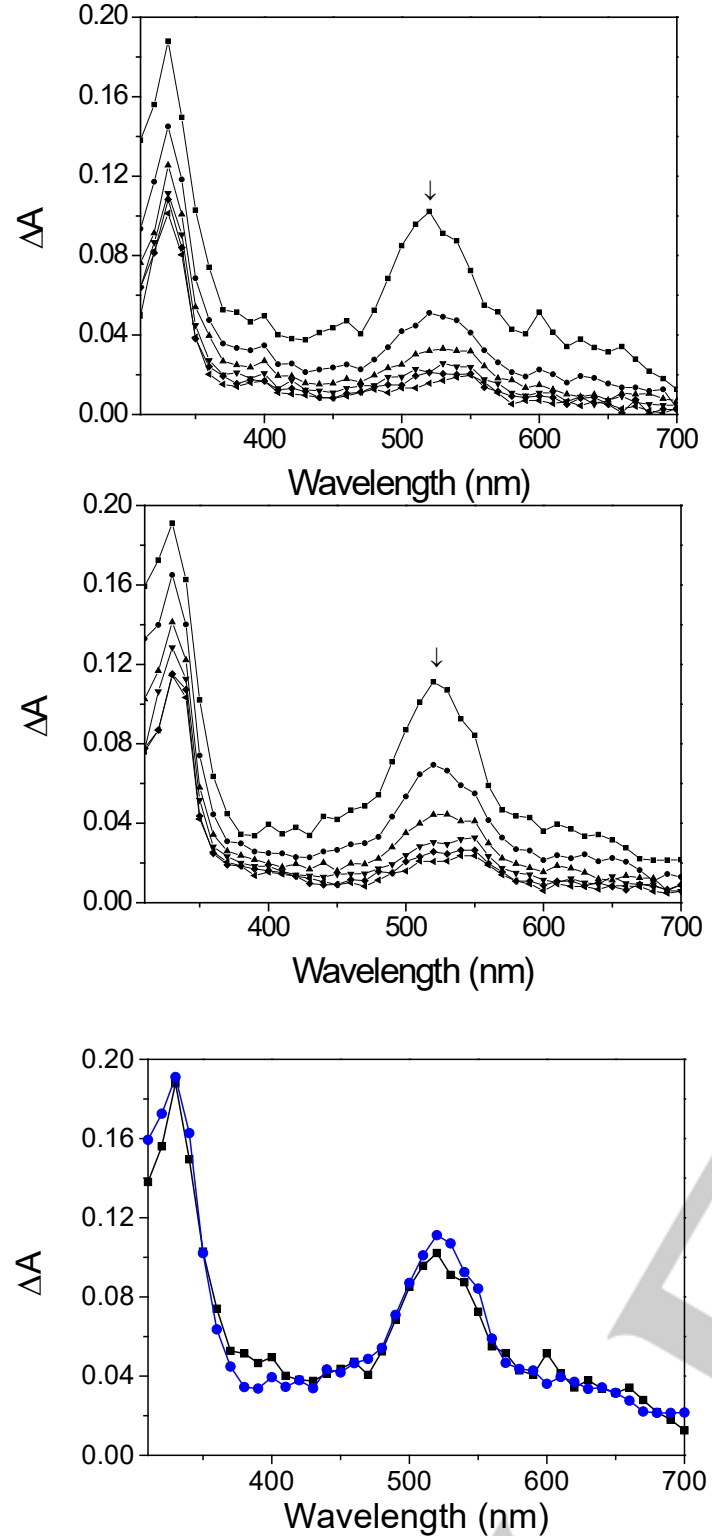

Figure 1. LFP $\left(\lambda_{\mathrm{exc}}=355 \mathrm{~nm}, \mathrm{CH}_{2} \mathrm{Cl}_{2}, \mathrm{~N}_{2}, 5 \times 10^{-4} \mathrm{M}\right.$ ) of 2 (top) and 1 (middle). Transient absorption spectra obtained at $0.5 \mu \mathrm{s}, 0.7 \mu \mathrm{s}, 1.1 \mu \mathrm{s}, 1.5 \mu \mathrm{s}, 1.9 \mu \mathrm{s}$ and $2.3 \mu \mathrm{s}$ after the laser pulse. Bottom: comparison of transient absorption spectra obtained $0.5 \mu \mathrm{s}$ after the laser pulse of 1 (blue) and 2 (black).

In addition to the spectroscopic evidence supporting formation of ${ }^{3}$ Thy ${ }^{*}$, kinetic evidence for the occurrence of TB-TTET from ${ }^{3} \mathrm{BP}^{*}$ to Thy was provided by the lifetime behavior of ${ }^{3} \mathrm{BP}^{*}$ in the systems. The decay of ${ }^{3} \mathrm{BP}^{*}$ was monitored at $520 \mathrm{~nm}$, and a clear decrease in the lifetime was observed in dyad $\mathbf{2}$ compared to the reference 1 (Figure 2, bottom). The decays were fitted to a first order exponential equation, and the lifetimes are summarized in Table 1. The rate constant of TB-TTET was determined for $\mathbf{2}$, and found to be $6.4 \times 10^{5} \mathrm{~s}^{-1}$. It is noteworthy that the presence of
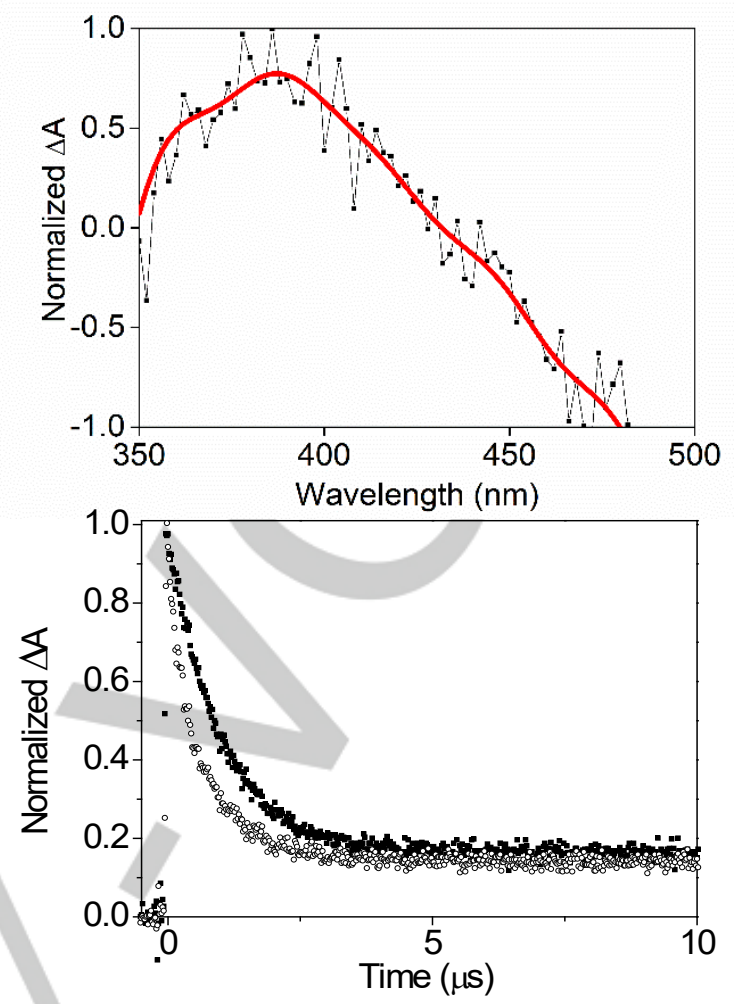

Figure 2. Top: Transient absorption spectra obtained from the algorithmic subtraction of the LFP traces (recorded with 2 average pulses every two $\mathrm{nm}$ ) corresponding to 2-1 at $0.5 \mu \mathrm{s}$. Bottom: Decays of $2(\circ)$ and $\mathbf{1}(\bullet)$ monitored at $520 \mathrm{~nm}$ upon LFP $\left(\lambda_{\mathrm{exc}}=355 \mathrm{~nm}, \mathrm{CH}_{2} \mathrm{Cl}_{2}, \mathrm{~N}_{2}, 5 \times 10^{-4} \mathrm{M}\right)$.

secondary alcohols in $\mathbf{1}$ and $\mathbf{2}$ may be contributing to shorten ${ }^{3} \mathrm{BP} *$ lifetime through hydrogen abstraction from the $\mathrm{C} \underline{\mathrm{H}}-\mathrm{OH}$ moieties. Thus, replacement of CA with LA was devised in order to improve our system, since $\mathbf{5}$ and $\mathbf{6}$ do not have such abstractable $\mathrm{H}$ (Scheme 2). Thus, transient absorption spectra of 5 upon selective excitation of BP clearly showed a significant absorption between 350 and $400 \mathrm{~nm}$, especially when compared to its reference compound 6 (Figures 3). Analogously to 1 and 2 , subtraction of the spectrum obtained for $\mathbf{6}$ from the one of $\mathbf{5}$, both taken $0.5 \mu$ s after the laser pulse, gave the trace corresponding to ${ }^{3}$ Thy $^{*}$, as shown in Figure 4 top. As anticipated, the lifetime of ${ }^{3} \mathrm{BP}$ in $\mathbf{5}(0.80 \mu \mathrm{s})$ is somewhat longer than that of ${ }^{3} \mathrm{BP}$ in $\mathbf{2}(0.61$ $\mu \mathrm{s})$, which allows for a better differentiation from its reference compound 6 (1.77 $\mu \mathrm{s}$, Table 1, Figure 4, bottom).

A further control experiment was performed to rule out a possible interference due to intermolecular TTET. Hence, a 1:1 mixture of 6 and $\mathrm{Thy}_{\mathrm{CH}} \mathrm{COOH}$ was submitted to LFP, and the transient absorption spectrum was recorded at the same times after the laser pulse (Figure S2). As expected, a clean spectrum was obtained exhibiting only the typical bands of ${ }^{3} \mathrm{BP}^{*}$, indicating that intermolecular TTET is negligible at the employed concentrations. Upon generating ${ }^{3}$ Thy $^{*}$, formation of Thy<> Thy should be favored, by the presence of an additional Thy unit in the media. With this idea in mind, systems $\mathbf{2}$ and $\mathbf{5}$ were independently submitted to steady-state photolysis experiments in the presence of one extra equivalent of Thy. Thus, the mixtures were selectively irradiated 

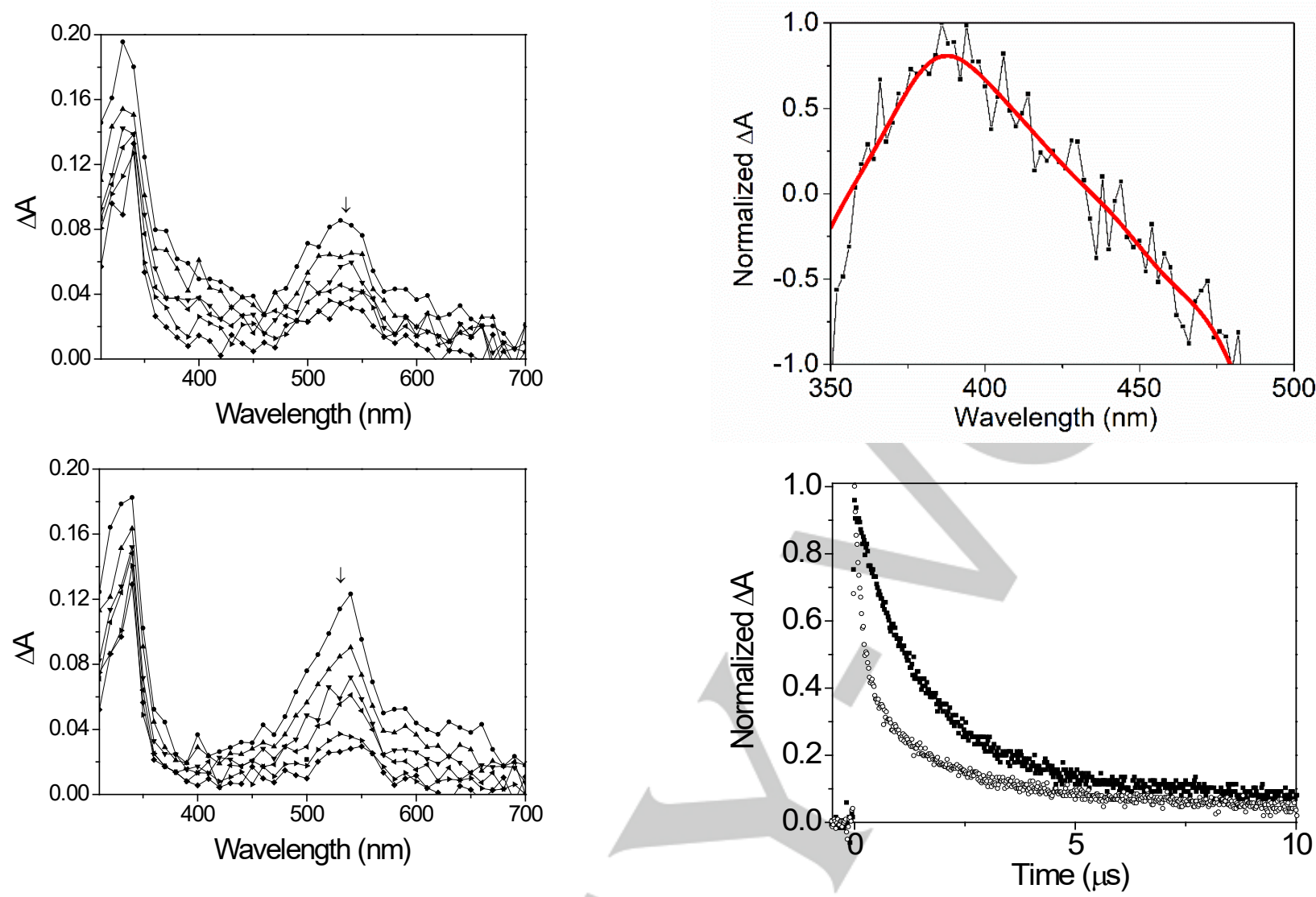

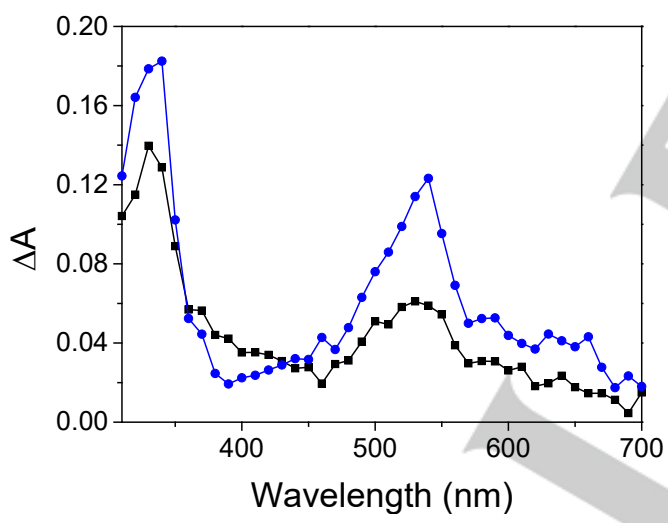

Figure 3. LFP ( $\lambda_{\text {exc }}=355 \mathrm{~nm}, \mathrm{CH}_{2} \mathrm{Cl}_{2}, \mathrm{~N}_{2}, 5 \times 10^{-4} \mathrm{M}$ ) of 5 (top) and 6 (middle) Transient absorption spectra obtained at $0.5 \mu \mathrm{s}, 1.0 \mu \mathrm{s}, 1.5 \mu \mathrm{s}, 2.0 \mu \mathrm{s}, 3.0 \mu \mathrm{s}$ and $4.0 \mu \mathrm{s}$ after the laser pulse. Bottom: comparison of transient absorption spectra obtained $0.5 \mu \mathrm{s}$ after the laser pulse of $\mathbf{6}$ (blue) and $\mathbf{5}$ (black).

at $\lambda_{\max }=350 \mathrm{~nm}$, where only the ${ }^{3} \mathrm{BP}^{*}$ chromophore absorbs, and their reactivity was monitored by UV-vis (Figure 5 top: $2+$ Thy and bottom: $\mathbf{5 + T h y , ~ i n ~ b o t h ~ c a s e s ~ a t ~ a ~ 1 : 1 ~ m o l a r ~ r a t i o ) . ~ I n ~ b o t h ~ c a s e s ~}$ a clear decrease in the absorbance was found, much more pronounced than in the control experiments carried out upon irradiation of 1 (Figure 6 top and S3) or with a mixture of $1+2$ eq of Thy (Figure S4) in which only a small decrease in the absorbance was observed.
Figure 4. Top: Transient absorption spectra obtained from the algorithmic subtraction of the LFP traces (recorded with 2 average pulses every two $\mathrm{nm}$ ) corresponding to 5-6 at $0.5 \mu \mathrm{s}$. Bottom: Decays of $5(\circ)$ and $\mathbf{6}(\square)$ monitored at $520 \mathrm{~nm}$ upon LFP $\left(\lambda_{\mathrm{exc}}=355 \mathrm{~nm}, \mathrm{CH}_{2} \mathrm{Cl}_{2}, \mathrm{~N}_{2}, 5 \times 10^{-4} \mathrm{M}\right)$.

Table 1. Triplet lifetimes and rate constants for TB-TTET in BP/Thy systems

\begin{tabular}{ccc}
\hline System $^{\mathrm{a}}$ & $\tau\left({ }^{3} \mathrm{BP}^{*}\right)$ in $\mu \mathrm{s}$ & $k\left(\mathrm{~s}^{-1}\right)^{\mathrm{b}, \mathrm{c}}$ \\
\hline $\mathbf{1}$ & 0.98 & N.A. \\
$\mathbf{2}$ & 0.61 & $6.4 \times 10^{5}$ \\
$\mathbf{6}$ & 1.77 & N.A. \\
$\mathbf{5}$ & 0.80 & $6.8 \times 10^{5}$ \\
\hline
\end{tabular}

aln all cases the concentration was $5 \times 10^{-4} \mathrm{M}$; bDetermined as $\left(1 / \tau_{2}-1 / \tau_{1}\right)$ for compound 2; cDetermined as $\left(1 / \tau_{5}-1 / \tau_{6}\right)$ for compound 5 

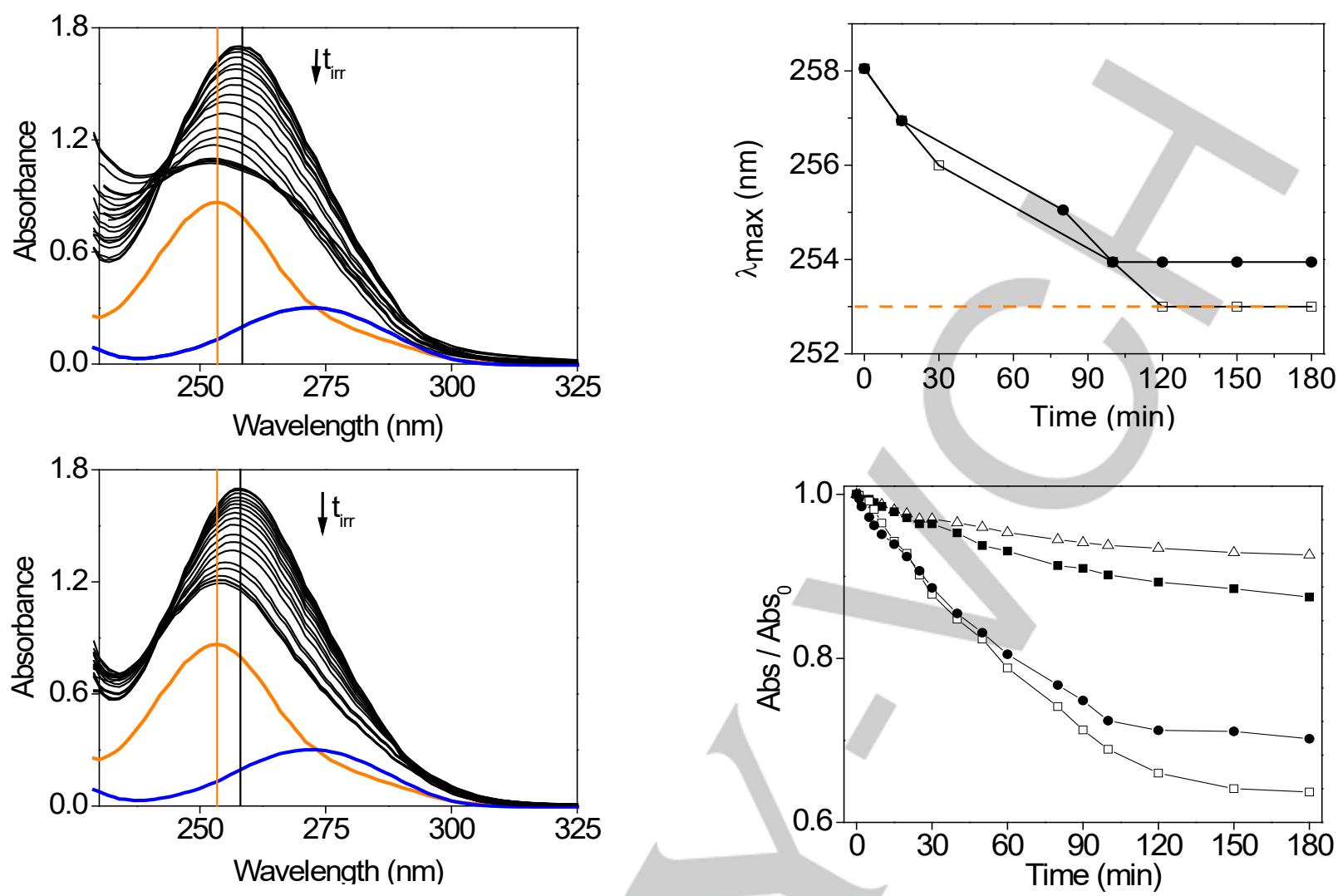

Figure 5. UV-vis spectra of $\mathbf{2}+$ Thy (top) and $\mathbf{5}+$ Thy (bottom) monitored at different irradiation times $\left(\mathrm{C}_{0}=4.4 \times 10^{-5} \mathrm{M}\right.$ each in $\left.\mathrm{CH}_{2} \mathrm{Cl}_{2}\right)$, inert atmosphere, $\lambda_{\max }=350 \mathrm{~nm}$ ); UV spectrum of BP (orange) and Thy (blue) recorded at $\mathrm{C}_{0}=$ $4.4 \times 10^{-5} \mathrm{M}$, for comparison.

Even more interesting was to observe that accompanying the decrease in the absorbance, the maximum experienced a blueshift, from $258 \mathrm{~nm}$ at the beginning to 253-255 nm after irradiation (see Figure 6 bottom). The decrease in the absorbance together with the blue-shift of the maximum could be safely interpreted in the two different systems as the result of the reaction between two Thy units, which would tend to give unreacted BP (orange trace in Figure 5 top and bottom) after complete conversion. Conversely, reaction of BP with one Thy unit to give an oxetane would lead to a final spectrum matching that of the reamining Thy (blue trace in Figure 5 top and bottom). Furthermore, for the case of the irradiation of $\mathbf{2}+$ Thy the photomixture was analyzed by UPLCMS. Selected ion monitoring revealed the presence of a peak with exact mass of 981.4893 corresponding to a formula of $\mathrm{C}_{54} \mathrm{H}_{69} \mathrm{~N}_{4} \mathrm{O}_{13}$ (calculated value 981.4861 ). This peak is consistent with the expected adduct resulting from the TB-TTET, followed by intermolecular [2+2] cycloaddition, which acted as a further confirmation of the process. Therefore, upon TB-TTET to the covalently attached Thy, the as generated ${ }^{3}$ Thy $^{*}$ in the presence of another Thy in the solution results in the formation of Thy<> Thy, leaving the BP chromophore unreacted. ${ }^{[13 b]}$. The participation of a through-space mechanism in the formation of the ${ }^{3}$ Thy $^{*}$ was further investigated upon determining the chromophorechromophore distances in compounds $\mathbf{2}$ and $\mathbf{5}$ using molecular dynamics at $298 \mathrm{~K}$ (see also Section S6 in the SI).

Figure 6. Top: Photoreaction kinetics of $\mathbf{2}+$ Thy (1: 1) ( $\square$ ), $\mathbf{5}+$ Thy (1: 1) (0) $\mathbf{1}+$ Thy $(1: 2)(\square)$ and $\mathbf{1}(\triangle)$. Bottom: Maximum shift observed upon irradiation of $\mathbf{2}+$ Thy $(1: 1)(\square)$ and $\mathbf{5}+$ Thy $(1: 1)(\mathbf{0})$; the maximum corresponding to BP is indicated in orange for comparison.

The effect of solvent affects the capability of molecules to fold and hence, this has been taken into account by including a large number of dichloromethane molecules in the simulation (see computational methods section for details). For each compound, 10000 configurations have been produced and their chromophore-chromophore distance employed to make the histograms shown in Figure 7.

Both compounds show a relatively narrow range of conformations with chromophore-chromophore distances in the range 15-25 $\AA$, with molecule $\mathbf{5}$ showing slightly shorter distances, indicating a larger capability to fold. Typical conformations obtained from the molecular dynamics calculation are shown in Figure 8.

A convenient expression to estimate the rate constant for an energy transfer process through a Dexter mechanism is given by: ${ }^{[17]}$

$$
k_{E T}=k_{0} \exp \left[-\beta\left(R_{D A}-R_{D A}^{0}\right)\right]
$$

Where $\mathrm{R}_{\mathrm{DA}}$ is the separation between the donor and the acceptor moieties and $R_{D A}^{0}$ is the separation corresponding to van der Waals contact. Typical values of $\beta$ are in the order of $1 \AA^{-1}$. In addition, the $k_{0}$ maximum value is assumed to be $10^{13} \mathrm{~s}^{-1}$; however, in structurally related BP-bile acid-thymine systems with 


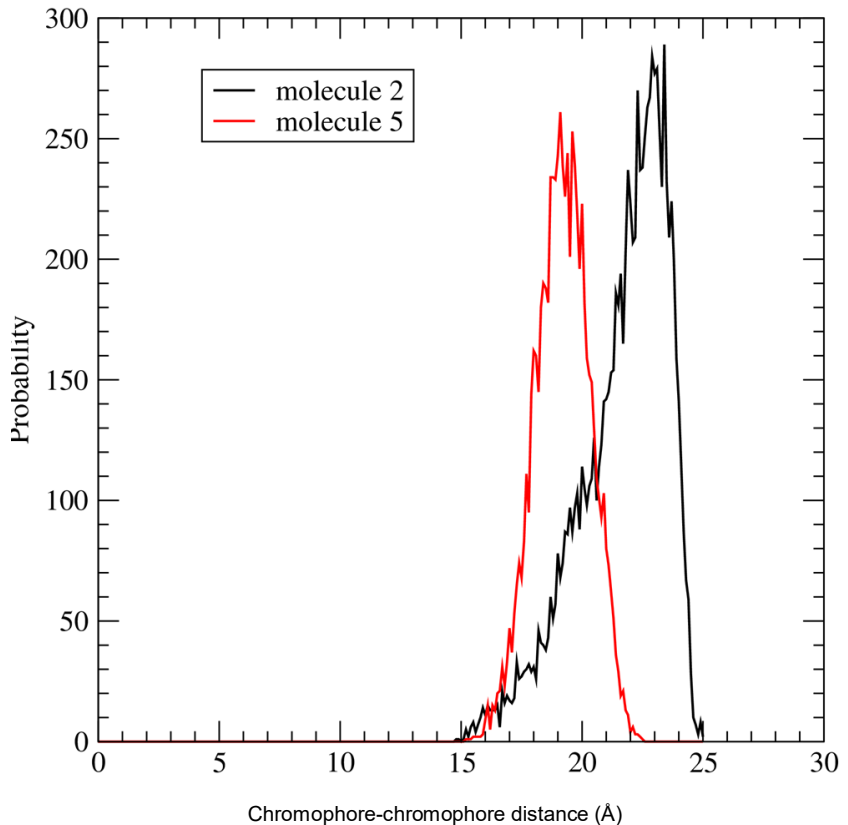

Figure 7. Histogram of chromophore-chromophore distances of compounds 2 and 5 obtained from molecular dynamics during $10 \mathrm{~ns}$ at $298 \mathrm{~K}$ in dichloromethane solvent. Each plot has been calculated using 10000
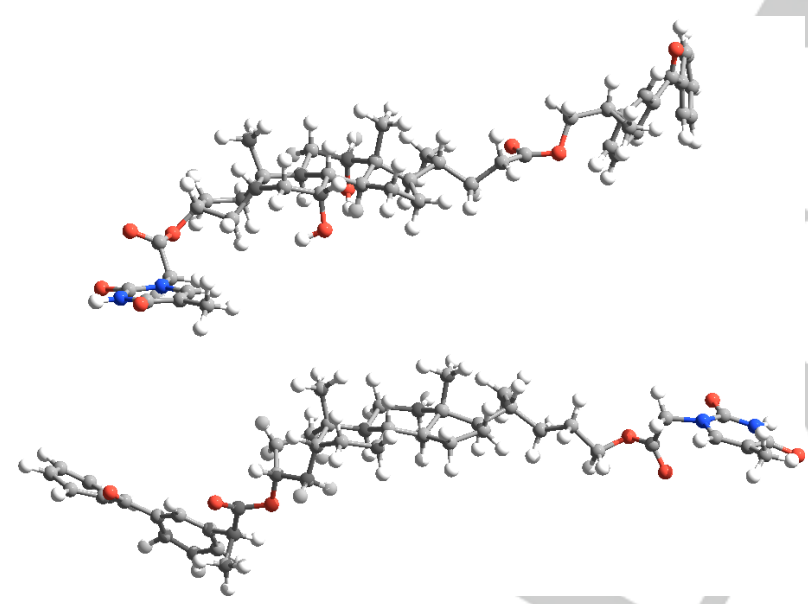

configurations.

Figure 8. Typical geometries of compounds 2 (top) and 5 (bottom) obtained from the molecular dynamics simulation.

a close contact between the chromophores $\mathrm{k}_{0}$ is markedly lower (ca. $\left.10^{7} \mathrm{~s}^{-1}\right)^{[13 \mathrm{~b}]}$ Using these data, the rate constant for through space energy transfer in compounds $\mathbf{2}$ and $\mathbf{5}$ would be lower than $10^{2} \mathrm{~s}^{-1}$. Thus, contribution of through space-TTET would be negligible and the only operating mechanism would be through bond-TTET.

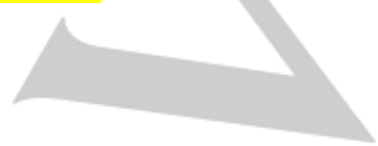

\section{Conclusions}

Time-resolved and steady-state spectroscopic evidence for the formation of ${ }^{3}$ Thy ${ }^{*}$ from ${ }^{3} \mathrm{BP}^{*}$ by through bond energy transfer has been provided in two different systems. To avoid interference of the well-known Paternò-Büchi reaction occurring with a high yield in these systems, a specific experimental strategy has been designed. Thus, one BP and one Thy have been covalently linked to the two ends of rigid skeletons of the natural cholic and lithocholic acids. This way, population of ${ }^{3} \mathrm{Thy}^{*}$ by triplet-triplet energy transfer from ${ }^{3} \mathrm{BP}^{*}$ has to occur through-bond, and competitive formation of oxetanes is avoided by placing the two chromophores at non-bonding distances. Further evidence has been provided by the formation of Thy<> Thy upon steady-state photolysis of the two dyads in the presence of one equivalent of Thy upon selective BP irradiation. The results shown here prove that it is possible to achieve efficient triplet energy transfer to a Thy unit even when the photosensitizer is at a distance as long as 15-25 A.

\section{Experimental Section}

General: 4-DMAP, anhydrous DMF, anhydrous pyridine, CA, DIEA, EDC, $\mathrm{HCl},(S)-\mathrm{KP}, \mathrm{LA}$, $\mathrm{LiAlH}_{4}, \mathrm{NH}_{4} \mathrm{Cl}$, TBTU, Thy- $\mathrm{CH}_{2} \mathrm{CO}_{2} \mathrm{H}$ and $\mathrm{CH}_{2} \mathrm{Cl}_{2}$ were purchased by Sigma-Aldrich.

Synthesis of 1: To a stirred mixture of CA $(0.671 \mathrm{~g}, 1.64 \mathrm{mmol}),(\mathrm{S})-\mathrm{KP}$ $\mathrm{OH}(0.328 \mathrm{~g}, 1.37 \mathrm{mmol})$ and 4-DMAP $(0.2 \mathrm{~g}, 1.64 \mathrm{mmol})$ in $8 \mathrm{~mL}$ of anhydrous pyridine at $0^{\circ} \mathrm{C}$, EDC $(0.290 \mathrm{~mL}, 1.64 \mathrm{mmol})$ was added dropwise and the reaction mixture was allowed to react for one hour and then overnight at $\mathrm{rt}$. The suspension was poured into $\mathrm{HCl} 1 \mathrm{M}$ and extracted with $\mathrm{CH}_{2} \mathrm{Cl}_{2}$. Then, the combined organic layers were washed with brine, dried over $\mathrm{MgSO}_{4}$ and concentrated under reduced pressure. Purification by column chromatography $\left(\mathrm{SiO}_{2}, \mathrm{CH}_{2} \mathrm{Cl}_{2}: \mathrm{MeOH}, 95: 5\right)$ gave 1 as a colorless solid $(0.516 \mathrm{~g}, 50 \%)$. ${ }^{1} \mathrm{H} \mathrm{NMR}\left(300 \mathrm{MHz}, \mathrm{CDCl}_{3}\right)$ : $\delta(\mathrm{ppm}) 0.66$ (s, 3H, 18- $\left.\mathrm{CH}_{3}\right) ; 0.89$ (s, 3H, 19- $\left.\mathrm{CH}_{3}\right) ; 0.94$ (d, $\left.J=6.3 \mathrm{~Hz}, 3 \mathrm{H}, 21-\mathrm{CH}_{3}\right)$; $1.34\left(\mathrm{~d}, 3 \mathrm{H}, J=7.2 \mathrm{~Hz}, \mathrm{KP}-\mathrm{CH}_{3}\right) ; 3.18(\mathrm{~m}, 1 \mathrm{H}, \mathrm{KP}-\mathrm{CH}) ; 3.46(\mathrm{~m}, 1 \mathrm{H}, 3 \beta-$ H); 3.84 (br s, $1 \mathrm{H}, 7 \beta-\mathrm{H}) ; 3.96$ (br s, $1 \mathrm{H}, 12 \beta-\mathrm{H}) ; 4.16$ (dd, $J=10.8,6.9 \mathrm{~Hz}$, $\left.1 \mathrm{H}, \mathrm{KP}-\mathrm{CH}_{2}\right) ; 4.21$ (dd, $\left.J=10.8,7.2 \mathrm{~Hz}, 1 \mathrm{H}, \mathrm{KP}_{-} \mathrm{CH}_{2}\right) ; 7.38-7.83(\mathrm{~m}, 9 \mathrm{H}$ arom). ${ }^{13} \mathrm{C} \mathrm{NMR}\left(75 \mathrm{MHz}, \mathrm{CDCl}_{3}\right): \delta(\mathrm{ppm}) 196.8$ (C), $174.3(\mathrm{C}), 143.8(\mathrm{C})$, $137.8(\mathrm{C}), 137.7(\mathrm{C}), 132.6(\mathrm{CH}), 131.5(\mathrm{CH}), 130.1(2 \times C H), 129.0(\mathrm{CH})$ $128.7(\mathrm{CH}), 128.5(\mathrm{CH}), 128.4(2 \times \mathrm{CH}), 73.1(\mathrm{CH}), 72.0(\mathrm{CH}), 68.9\left(\mathrm{CH}_{2}\right)$, $68.5(\mathrm{CH}), 47.1(\mathrm{CH}), 46.5(\mathrm{C}), 41.7(\mathrm{CH}), 41.6(\mathrm{CH}), 39.6(\mathrm{CH}), 39.0(\mathrm{CH})$, $35.4\left(\mathrm{CH}_{2}\right), 35.3(\mathrm{CH}), 34.9(\mathrm{C}), 34.8\left(\mathrm{CH}_{2}\right), 31.4\left(\mathrm{CH}_{2}\right), 31.0\left(\mathrm{CH}_{2}\right), 30.5$ $\left(\mathrm{CH}_{2}\right), 29.8\left(\mathrm{CH}_{2}\right), 28.3\left(\mathrm{CH}_{2}\right), 27.6\left(\mathrm{CH}_{2}\right), 26.4(\mathrm{CH}), 23.3\left(\mathrm{CH}_{2}\right), 22.6$ $\left(\mathrm{CH}_{3}\right), 18.1\left(\mathrm{CH}_{3}\right), 17.4\left(\mathrm{CH}_{3}\right), 12.6\left(\mathrm{CH}_{3}\right) . \mathrm{HRMS}, \mathrm{m} / \mathrm{z}$ found 631.3989 , calculated for $\mathrm{C}_{40} \mathrm{H}_{55} \mathrm{O}_{6}\left(\mathrm{MH}^{+}\right) 631.3999$.

Synthesis of 2: To a stirred solution of Thy- $\mathrm{CH}_{2} \mathrm{CO}_{2} \mathrm{H}(0.360 \mathrm{~g}, 1.96$ $\mathrm{mmol})$ in anhydrous DMF $(2.5 \mathrm{~mL})$, a solution of 4-DMAP $(0.093 \mathrm{~g}, 0.77$ $\mathrm{mmol})$ and $1(0.374 \mathrm{~g}, 0.59 \mathrm{mmol})$ in DMF $(2 \mathrm{~mL})$ was added dropwise. Then the resulting suspension was cooled at $0{ }^{\circ} \mathrm{C}, \operatorname{EDC}(0.35 \mathrm{~mL}, 1.96$ $\mathrm{mmol}$ ) was added and after one hour at $0{ }^{\circ} \mathrm{C}$, the reaction mixture was allowed to stir overnight at rt. Then, the suspension was poured into $\mathrm{HCl}$ $1 \mathrm{M}$, extracted with $\mathrm{CH}_{2} \mathrm{Cl}_{2}$ and the combined organic extracts were washed with brine, dried over $\mathrm{MgSO}_{4}$ and concentrated. After purification by column chromatography $\left(\mathrm{SiO}_{2}\right.$, EtOAc:hexane, $\left.90: 10\right)$ followed by $(\mathrm{Li}$ Chroprep RP-18, $\left.\mathrm{CH}_{3} \mathrm{CN}: \mathrm{H}_{2} \mathrm{O}, 80: 20\right), 2$ was obtained as a colorless solid (0.298 g, 63\%). ${ }^{1} \mathrm{H}$ NMR (300 MHz, $\left.\mathrm{CDCl}_{3}\right): \delta(\mathrm{ppm}) 0.64$ (s, 3H, 18- $\mathrm{CH}_{3}$ ); 
$0.88\left(\mathrm{~s}, 3 \mathrm{H}, 19-\mathrm{CH}_{3}\right) ; 0.94$ (d, $\left.J=6.0 \mathrm{~Hz}, 3 \mathrm{H}, 21-\mathrm{CH}_{3}\right) ; 1.32$ (d, $3 \mathrm{H}, J=6.9$ $\left.\mathrm{Hz}, \mathrm{KP}-\mathrm{CH}_{3}\right) ; 1.86$ (br s, $3 \mathrm{H}$, Thy- $\left.\mathrm{CH}_{3}\right) ; 3.16(\mathrm{~m}, 1 \mathrm{H}, \mathrm{KP}-\mathrm{CH}) ; 3.82$ (br s, $1 \mathrm{H}, 7 \beta-\mathrm{H}) ; 3.96$ (br s, $1 \mathrm{H}, 12 \beta-\mathrm{H}) ; 4.17\left(\mathrm{~m}, 2 \mathrm{H}, \mathrm{KP}-\mathrm{CH}_{2}\right) ; 4.34$ (d, $1 \mathrm{H}, J=$ $16.8 \mathrm{~Hz}$, Thy- $\left.\mathrm{CH}_{2}\right) ; 4.47\left(\mathrm{~d}, 1 \mathrm{H}, J=16.8 \mathrm{~Hz}\right.$, Thy- $\left.\mathrm{CH}_{2}\right) ; 4.59(\mathrm{~m}, 1 \mathrm{H}, 3 \beta-$ $\mathrm{H}) ; 7.10$ (s, $1 \mathrm{H}$, Thy-CH); 7.38-7.80 (m, 9H, arom); 9.20 (br s, $1 \mathrm{H}$, Thy-NH). ${ }^{13} \mathrm{C}$ NMR (75 MHz, CDCl 3 ): $\delta$ (ppm) 196.8 (C), 174.2 (C), 167.7 (C), 164.6 (C), $151.4(\mathrm{C}), 143.8(\mathrm{CH}), 141.3(\mathrm{C}), 137.8(\mathrm{C}), 137.7(\mathrm{C}), 132.6(\mathrm{CH})$, $131.5(\mathrm{CH}), 130.1(2 \times \mathrm{CH}), 129.0(\mathrm{CH}), 128.7(\mathrm{CH}), 128.4(\mathrm{CH}), 128.3$ $(2 \times C H), 110.6(\mathrm{C}), 76.9(\mathrm{CH}), 72.8(\mathrm{CH}), 68.9\left(\mathrm{CH}_{2}\right), 68.2(\mathrm{CH}), 49.5\left(\mathrm{CH}_{2}\right)$ $47.1(\mathrm{CH}), 46.4(\mathrm{C}), 42.0(\mathrm{CH}), 41.3(\mathrm{CH}), 39.7(\mathrm{CH}), 39.0(\mathrm{CH}), 35.1(\mathrm{CH})$, $35.0\left(\mathrm{CH}_{2}\right), 34.9\left(\mathrm{CH}_{2}\right), 34.8(\mathrm{C}), 34.4\left(\mathrm{CH}_{2}\right), 31.3\left(\mathrm{CH}_{2}\right), 31.0\left(\mathrm{CH}_{2}\right), 28.5$ $\left(\mathrm{CH}_{2}\right), 27.5\left(\mathrm{CH}_{2}\right), 26.7(\mathrm{CH}), 26.3\left(\mathrm{CH}_{2}\right), 23.2\left(\mathrm{CH}_{2}\right), 22.6\left(\mathrm{CH}_{3}\right), 18.1$ $\left(\mathrm{CH}_{3}\right), 17.3\left(\mathrm{CH}_{3}\right), 12.6\left(\mathrm{CH}_{3}\right), 12.3\left(\mathrm{CH}_{3}\right)$. HRMS, m/z found 797.4388, calculated for $\mathrm{C}_{47} \mathrm{H}_{61} \mathrm{~N}_{2} \mathrm{O}_{9}\left(\mathrm{MH}^{+}\right)$797.4377.

Synthesis of 3: To a stirred suspension of $\mathrm{LiAlH}_{4}(0.29 \mathrm{~g}, 7.59 \mathrm{mmol})$ in anhydrous THF $(5.5 \mathrm{~mL})$ at $-10^{\circ} \mathrm{C}$, a solution of LA $(1.00 \mathrm{~g}, 2.66 \mathrm{mmol})$ in anhydrous THF $(100 \mathrm{~mL})$ was slowly added and the reaction mixture was refluxed overnight. Afterwards, it was quenched with saturated aqueous $\mathrm{NH}_{4} \mathrm{Cl}$ solution, poured into aqueous $\mathrm{HCl} 1 \mathrm{M}$ and extracted with EtOAc. The combined organic layers were washed with brine, dried over $\mathrm{MgSO}_{4}$ and concentrated. Purification by column chromatography (Li Chroprep RP-18, MeOH: $\left.\mathrm{H}_{2} \mathrm{O}, 90: 10\right)$ gave 3 as a colorless solid $(0.85 \mathrm{~g}$, $88 \%$ ). ${ }^{1} \mathrm{H} \mathrm{NMR}(300 \mathrm{MHz}, \mathrm{CDCl} 3): \delta(\mathrm{ppm}) 0.64$ (s, 3H, 18- $\left.\mathrm{CH}_{3}\right) ; 0.92$ (s, $\left.3 \mathrm{H}, 19-\mathrm{CH}_{3}\right) ; 0.93\left(\mathrm{~d}, \mathrm{~J}=6.3 \mathrm{~Hz}, 3 \mathrm{H}, 21-\mathrm{CH}_{3}\right) ; 3.61\left(\mathrm{~m}, 3 \mathrm{H}, 3 \beta-\mathrm{H}+\mathrm{CH}_{2}\right)$. ${ }^{13} \mathrm{C} \mathrm{NMR}\left(75 \mathrm{MHz}, \mathrm{CDCl}_{3}\right): \delta(\mathrm{ppm}) 72.0(\mathrm{CH}), 63.8\left(\mathrm{CH}_{2}\right), 56.7(\mathrm{CH})$, $56.3(\mathrm{CH}), 42.9(\mathrm{C}), 42.3(\mathrm{CH}), 40.6(\mathrm{CH}), 40.4\left(\mathrm{CH}_{2}\right), 36.6\left(\mathrm{CH}_{2}\right), 36.0$ $(\mathrm{CH}), 35.7(\mathrm{CH}), 35.5\left(\mathrm{CH}_{2}\right), 34.7(\mathrm{C}), 32.0\left(\mathrm{CH}_{2}\right), 30.7\left(\mathrm{CH}_{2}\right), 29.6\left(\mathrm{CH}_{2}\right)$, $28.5\left(\mathrm{CH}_{2}\right), 27.4\left(\mathrm{CH}_{2}\right), 26.6\left(\mathrm{CH}_{2}\right), 24.4\left(\mathrm{CH}_{2}\right), 23.5\left(\mathrm{CH}_{3}\right), 21.0\left(\mathrm{CH}_{2}\right)$, $18.8\left(\mathrm{CH}_{3}\right), 12.2\left(\mathrm{CH}_{3}\right)$.

Synthesis of 4: To a stirred solution of $3(0.56 \mathrm{~g}, 1.54 \mathrm{mmol})$ and TBTU $(0.59 \mathrm{~g}, 1.85 \mathrm{mmol})$ in anhydrous DMF $(8 \mathrm{~mL})$, Thy- $\mathrm{CH}_{2} \mathrm{CO}_{2} \mathrm{H}(0.30 \mathrm{~g}$, $1.62 \mathrm{mmol}$ ) in DMF (6 mL) followed by DIEA $(0.80 \mathrm{~mL}, 4.62 \mathrm{mmol})$ were added dropwise, and then the reaction mixture was allowed to react overnight at rt. Afterwards, it was poured into brine and extracted with $\mathrm{CH}_{2} \mathrm{Cl}_{2}$; the combined organic layers were washed with brine, dried over $\mathrm{MgSO}_{4}$ and concentrated under reduced pressure. Purification by column chromatography $\left(\mathrm{SiO}_{2}\right.$, EtOAc:Hex, 70:30) followed by (Li Chroprep RP$\left.18, \mathrm{CH}_{3} \mathrm{CN}: \mathrm{H}_{2} \mathrm{O}, 90: 10\right)$ gave 4 as a colorless oil $(0.29 \mathrm{~g}, 36 \%) .{ }^{1} \mathrm{H}$ NMR $\left(300 \mathrm{MHz}, \mathrm{CDCl}_{3}\right): \delta(\mathrm{ppm}) 0.65\left(\mathrm{~s}, 3 \mathrm{H}, 18-\mathrm{CH}_{3}\right) ; 0.92(\mathrm{~d}, J=6.3 \mathrm{~Hz}, 3 \mathrm{H}$, 21- $\left.\mathrm{CH}_{3}\right) ; 0.93\left(\mathrm{~s}, 3 \mathrm{H}, 19-\mathrm{CH}_{3}\right) ; 1.94\left(\mathrm{~d}, J=1.2 \mathrm{~Hz}, 3 \mathrm{H}\right.$, Thy- $\left.\mathrm{CH}_{3}\right) ; 3.64(\mathrm{~m}$, $1 \mathrm{H}, 3 \beta-\mathrm{H}) ; 4.16\left(\mathrm{~m}, 2 \mathrm{H}, \mathrm{CH}_{2}\right), 4.45\left(\mathrm{~s}, 2 \mathrm{H}\right.$, Thy- $\left.\mathrm{CH}_{2}\right) ; 6.95(\mathrm{br} \mathrm{s}, 1 \mathrm{H}$, Thy$\mathrm{CH}) ; 9.06$ (s, $1 \mathrm{H}$, Thy-NH). ${ }^{13} \mathrm{C} \mathrm{NMR}\left(75 \mathrm{MHz}, \mathrm{CDCl}_{3}\right): \delta$ (ppm) 167.7 (C), $164.2(\mathrm{C}), 150.9(\mathrm{C}), 140.3(\mathrm{CH}), 111.4(\mathrm{C}), 72.0(\mathrm{CH}), 66.9\left(\mathrm{CH}_{2}\right), 56.6$ $(\mathrm{CH}), 56.1(\mathrm{CH}), 48.7\left(\mathrm{CH}_{2}\right), 42.9(\mathrm{C}), 42.2(\mathrm{CH}), 40.6(\mathrm{CH}), 40.3\left(\mathrm{CH}_{2}\right)$, $36.6\left(\mathrm{CH}_{2}\right), 36.0(\mathrm{CH}), 35.4\left(\mathrm{CH}+\mathrm{CH}_{2}\right), 34.7(\mathrm{C}), 32.0\left(\mathrm{CH}_{2}\right), 30.7\left(\mathrm{CH}_{2}\right)$, $28.4\left(\mathrm{CH}_{2}\right), 27.3\left(\mathrm{CH}_{2}\right), 26.6\left(\mathrm{CH}_{2}\right), 25.2\left(\mathrm{CH}_{2}\right), 24.4\left(\mathrm{CH}_{2}\right), 23.5\left(\mathrm{CH}_{3}\right)$, $21.0\left(\mathrm{CH}_{2}\right), 18.7\left(\mathrm{CH}_{3}\right), 12.5\left(\mathrm{CH}_{3}\right), 12.2\left(\mathrm{CH}_{3}\right) . \mathrm{HRMS}, \mathrm{m} / \mathrm{z}$ found 529.3638, calculated for $\mathrm{C}_{31} \mathrm{H}_{49} \mathrm{~N}_{2} \mathrm{O}_{5}\left(\mathrm{MH}^{+}\right) 529.3641$.

Synthesis of 5: To a stirred solution of $4(0.129 \mathrm{~g}, 0.24 \mathrm{mmol})$ and TBTU $(0.12 \mathrm{~g}, 0.36 \mathrm{mmol})$ in anhydrous DMF $(1 \mathrm{~mL}), \mathrm{KP}(0.09 \mathrm{~g}, 0.36 \mathrm{mmol})$ in DMF $(2.5 \mathrm{~mL})$ followed by DIEA $(0.16 \mathrm{~mL}, 0.9 \mathrm{mmol})$ were added dropwise and then the reaction mixture was allowed to react overnight at rt. Afterwards, it was poured into brine and extracted with $\mathrm{CH}_{2} \mathrm{Cl}_{2}$; the combined organic layers were washed with brine, dried over $\mathrm{MgSO}_{4}$ and concentrated under reduced pressure. Purification by column chromatography $\left(\mathrm{SiO}_{2}\right.$, EtOAc:Hex, 50:50) followed by (Li Chroprep RP$\left.18, \mathrm{CH}_{3} \mathrm{CN}: \mathrm{H}_{2} \mathrm{O}, 90: 10\right)$ gave 5 as a colorless oil $(0.14 \mathrm{~g}, 73 \%) .{ }^{1} \mathrm{H}$ NMR $\left(300 \mathrm{MHz}, \mathrm{CDCl}_{3}\right): \delta$ (ppm) $0.62\left(\mathrm{~s}, 3 \mathrm{H}, 18-\mathrm{CH}_{3}\right) ; 0.89$ (br s, 6H, 19$\left.\mathrm{CH}_{3}+21-\mathrm{CH}_{3}\right) ; 1.49$ (d, $\left.J=6.9 \mathrm{~Hz}, 3 \mathrm{H}, \mathrm{KP}-\mathrm{CH}_{3}\right) ; 1.91(\mathrm{~d}, J=1.2 \mathrm{~Hz}, 3 \mathrm{H}$, Thy- $\left.\mathrm{CH}_{3}\right) ; 3.74(\mathrm{~m}, 1 \mathrm{H}, \mathrm{KP}-\mathrm{CH}) ; 4.12\left(\mathrm{~m}, 2 \mathrm{H}, \mathrm{CH}_{2}\right), 4.43\left(\mathrm{~s}, 2 \mathrm{H}\right.$, Thy- $\left.\mathrm{CH}_{2}\right)$; $4.72(\mathrm{~m}, 1 \mathrm{H}, 3 \beta-\mathrm{H}) ; 6.94(\mathrm{brs}, 1 \mathrm{H}$, Thy-CH); 7.37-7.81 (m, $9 \mathrm{H}$, arom); 9.35 (s, $1 \mathrm{H}$, Thy-NH). ${ }^{13} \mathrm{C}$ NMR $\left(75 \mathrm{MHz}, \mathrm{CDCl}_{3}\right): \delta$ (ppm) 196.7 (C), 173.7 (C), 167.7 (C), 164.3 (C), 151.0 (C), $141.2(\mathrm{C}), 140.3(\mathrm{CH}), 137.9$ (C), 137.6 (C), $132.6(\mathrm{CH}), 131.6(\mathrm{CH}), 130.2(2 \times \mathrm{CH}), 129.3(\mathrm{CH}), 128.9(\mathrm{CH}), 128.6$
(CH), $128.4(2 \times C H), 111.3(\mathrm{C}), 75.0(\mathrm{CH}), 66.8\left(\mathrm{CH}_{2}\right), 56.5(\mathrm{CH}), 56.1(\mathrm{CH})$, $48.7\left(\mathrm{CH}_{2}\right), 45.8(\mathrm{CH}), 42.8(\mathrm{C}), 42.0(\mathrm{CH}), 40.5(\mathrm{CH}), 40.2\left(\mathrm{CH}_{2}\right), 35.9$ $(\mathrm{CH}), 35.4(\mathrm{CH}), 35.0\left(\mathrm{CH}_{2}\right), 34.7(\mathrm{C}), 32.1\left(\mathrm{CH}_{2}\right), 31.9\left(\mathrm{CH}_{2}\right), 28.4\left(\mathrm{CH}_{2}\right)$, $27.1\left(\mathrm{CH}_{2}\right), 26.7\left(\mathrm{CH}_{2}\right), 26.4\left(\mathrm{CH}_{2}\right), 25.1\left(\mathrm{CH}_{2}\right), 24.3\left(\mathrm{CH}_{2}\right), 23.4\left(\mathrm{CH}_{3}\right)$, $20.9\left(\mathrm{CH}_{2}\right), 18.7\left(\mathrm{CH}_{3}\right), 18.6\left(\mathrm{CH}_{3}\right), 12.5\left(\mathrm{CH}_{3}\right), 12.1\left(\mathrm{CH}_{3}\right) . \mathrm{HRMS}, \mathrm{m} / \mathrm{z}$ found 765.4500 , calculated for $\mathrm{C}_{47} \mathrm{H}_{61} \mathrm{~N}_{2} \mathrm{O}_{7}\left(\mathrm{MH}^{+}\right) 765.4479$.

Synthesis of 6: To a solution of $\mathrm{KP}(0.203 \mathrm{~g}, 0.8 \mathrm{mmol})$ in $\mathrm{CH}_{2} \mathrm{Cl}_{2}(10 \mathrm{~mL})$, DCC $(0.207 \mathrm{~g}, 0.85 \mathrm{mmol})$ and 4-DMAP (catalytic amount) were added as solids. The reaction was stirred while LA $(0.301 \mathrm{~g}, 0.8 \mathrm{mmol})$ in $5 \mathrm{~mL}$ of $\mathrm{CH}_{2} \mathrm{Cl}_{2}$ was added dropwise. After $24 \mathrm{~h}$, the crude product was washed with diluted $\mathrm{NaHCO}_{3}, \mathrm{HCl} 1 \mathrm{M}$ and brine. Final purification by preparative layer chromatography $\left(\mathrm{SiO}_{2}\right.$ Merck 60 PF254, EtOAc:Hexane, 80:20) followed by recrystallization gave $6(0.343 \mathrm{~g}, 70 \%) .{ }^{1} \mathrm{H} \mathrm{NMR}(400 \mathrm{MHz}$, $\mathrm{CD}_{3} \mathrm{OD}$ ): $\delta(\mathrm{ppm}) 0.64\left(\mathrm{~s}, 3 \mathrm{H}, \mathrm{CH}_{3}\right) ; 0.65\left(\mathrm{~s}, 3 \mathrm{H}, \mathrm{CH}_{3}\right) ; 0.91(\mathrm{~d}, J=6.3 \mathrm{~Hz}$, $\left.3 \mathrm{H}, \mathrm{CH}_{3}\right) ; 1.51$ (d, $\left.J=7.2 \mathrm{~Hz}, 3 \mathrm{H}, \mathrm{KP}-\mathrm{CH}_{3}\right) ; 3.75$ (q, $J=7.2 \mathrm{~Hz}, 1 \mathrm{H}, \mathrm{KP}-$ $\mathrm{CH}) ; 4.72(\mathrm{~m}, 1 \mathrm{H}, 3 \beta-\mathrm{H}) ; 7.40-7.84\left(\mathrm{~m}, 9 \mathrm{H}\right.$, arom). ${ }^{13} \mathrm{C}$ NMR $(100 \mathrm{MHz}$, $\mathrm{CD}_{3} \mathrm{OD}$ ): $\delta$ (ppm) 196.8 (C), 179.3 (C), 173.9 (C), $141.3(\mathrm{C}), 138.0(\mathrm{C})$, $137.7(\mathrm{C}), 132.6(\mathrm{CH}), 131.6(\mathrm{CH}), 130.2(2 \times C H), 129.4(\mathrm{CH}), 129.0(\mathrm{CH})$, $128.7(\mathrm{CH}), 128.4(2 \times \mathrm{CH}), 74.2(\mathrm{CH}), 56.7(\mathrm{CH}), 56.2(\mathrm{CH}), 45.8(\mathrm{CH})$, $42.9(\mathrm{C}), 42.1(\mathrm{CH}), 40.6(\mathrm{CH}), 40.3\left(\mathrm{CH}_{2}\right), 36.0(\mathrm{CH}), 35.5(\mathrm{CH}), 35.2$ $\left(\mathrm{CH}_{2}\right), 34.7(\mathrm{C}), 32.4\left(\mathrm{CH}_{2}\right), 31.9\left(\mathrm{CH}_{2}\right), 31.2\left(\mathrm{CH}_{2}\right), 31.0\left(\mathrm{CH}_{2}\right), 28.3\left(\mathrm{CH}_{2}\right)$, $27.2\left(\mathrm{CH}_{2}\right), 26.5\left(\mathrm{CH}_{2}\right), 24.3\left(\mathrm{CH}_{2}\right), 23.5\left(\mathrm{CH}_{3}\right), 21.0\left(\mathrm{CH}_{2}\right), 18.8\left(\mathrm{CH}_{3}\right)$, $18.4\left(\mathrm{CH}_{3}\right), 12.2\left(\mathrm{CH}_{3}\right)$. HRMS, $\mathrm{m} / \mathrm{z}$ found 613.3893 , calculated for $\mathrm{C}_{40} \mathrm{H}_{53} \mathrm{O}_{5}\left(\mathrm{MH}^{+}\right) 613.3896$.

\section{Acknowledgements}

Financial support from the Spanish Government (Grants SEV2016-0683 and Projects CTQ2012-38754-C03-03 and CTQ201570164P), Generalitat Valenciana (Prometeo Program) and UPV (Predoctoral FPI fellowship for P. Miró) is gratefully acknowledged.

Keywords: Benzophenone • Bile Acid • DNA • Laser Flash Photolysis • Oxetane

[1] a) S. Mouret, C. Baudouin, M. Charveron, A. Favier, J. Cadet and T. Douki, Proc. Natl. Acad. Sci. 2006, 103, 13765-13770; b) R. B. Setlow, E. Grist, K. Thompson and A. D. Woodhead, Proc. Natl. Acad. Sci. 1993, 90, 6666-6670; c) P. J. Rochette, J.-P. Therrien, R. Drouin, D. Perdiz, N. Bastien, E. A. Drobetsky and E. Sage, Nucl. Acids Res. 2003, 31, 2786-2794.

[2] a) C. A. Smith, M. Wang, N. Jiang, L. Che, X. Zhao and J.-S. Taylor, Biochemistry 1996, 35, 4146-4154; b) A. Gentil, F. Le Page, A. Borden and A. Sarasin, Nucl. Acids Res. 1996, 24, 1837-1840.

[3] a) H. Gorner, J Photochem Photobiol B 1990, 5, 359-377; b) A. A. Lamola and J. Eisinger, Biochim. Biophys. Acta 1971, 240, 313-325. [4] M. C. Cuquerella, V. Lhiaubet-Vallet, F. Bosca and M. A. Miranda, Chem. Sci. 2011, 2, 1219-1232.

[5] a) L. Blancafort and A. A. Voityuk, Phys. Chem. Chem. Phys. 2018, 20, 4997-5000; b) L. Antusch, N. Gaß and H. A. Wagenknecht, Angew. Chem. Int. Ed. 2017, 56, 1385-1389.

[6] a) S. Kanvah, J. Joseph, G. B. Schuster, R. N. Barnett, C. L. Cleveland and U. Landman, Acc. Chem. Res. 2010, 43, 280-287; b) B. Giese, J. Amaudrut, A. K. Kohler, M. Spormann and S. Wessely, Nature 2001, 412, 318-320; c) B. Giese, Acc. Chem. Res. 2000, 33 , 631-636; d) T. Takada, K. Kawai, M. Fujitsuka and T. Majima, Proc. Natl. Acad. Sci. 2004, 101, 14002-14006; e) T. Takada, K. Kawai, X. C. Cai, A. Sugimoto, M. Fujitsuka and T. Majima, J. Am. Chem. Soc. 2004, 126, 1125-1129; f) T. Takada, M. Fujitsuka and T. Majima, Proc. Natl. Acad. Sci. 2007, 104, 11179-11183; g) K. Kawai and T. Majima, Acc. Chem. Res. 2013, 46, 2616-2625; h) K. Kawai, H. Kodera, Y. Osakada and T. Majima, Nat. Chem. 2009, 1, 156-159; i) K. Kawai, H. Kodera and T. Majima, J. Am. Chem. Soc. 2010, 132, 627-630.

[7] a) B. Giese, B. Carl, T. Carl, T. Carell, C. Behrens, U. Hennecke, O. Schiemann and E. Feresin, Angew. Chem., Int. Ed. 2004, 43, 
1848-1851; b) M. J. Park, M. Fujitsuka, K. Kawai and T. Majima, J. Am. Chem. Soc. 2011, 133, 15320-15323; c) S.-H. Lin, M. Fujitsuka and T. Majima, J. Phys. Chem. B 2016; d) A. Manetto, S. Breeger, C. Chatgilialoglu and T. Carell, Angew. Chem., Int. Ed. 2006, 45, 318321; e) K. Heil, D. Pearson and T. Carell, Chem. Soc. Rev. 2011, 40, 4271-4278; f) C. Haas, K. Kraling, M. Cichon, N. Rahe and T. Carell, Angew. Chem., Int. Ed. 2004, 43, 1842-1844; g) T. Carell, Angew. Chem. Int. Ed. 1995, 34, 2491-2494; h) S. Breeger, U. Hennecke and T. Carell, J. Am. Chem. Soc. 2004, 126, 1302-1303.

[8] a) M. C. Cuquerella, V. Lhiaubet-Vallet, J. Cadet and M. A. Miranda, Acc. Chem. Res. 2012, 45, 1558-1570; b) T. Delatour, T. Douki, C. D'Ham and J. Cadet, J. Photochem. Photobiol., B 1998, 44, 191-198; C) P. D. Wood and R. W. Redmond, J. Am. Chem. Soc. 1996, 118, 4256-4263.

[9] a) W. J. Schreier, T. E. Schrader, F. O. Koller, P. Gilch, C. E. Crespo-Hernandez, V. N. Swaminathan, T. Carell, W. Zinth and B. Kohler, Science 2007, 315, 625-629; b) W. J. Schreier, J. Kubon, N. Regner, K. Haiser, T. E. Schrader, W. Zinth, P. Clivio and P. Gilch, J. Am. Chem. Soc. 2009, 131, 5038-5039.

[10] S. L. Murov, I. Carmichael and G. L. Hug in Handbook of Photochemistry, Vol. (Ed. M. Dekker), New York, 2009.

[11] K. Sandros, Acta Chem. Scand. 1964, 18, 2355-2374.

[12] T. Douki, I. Berard, A. Wack and S. Andrae, Chem. Eur. J. 2014, 20, 5787-5794.

[13] a) I. G. Gut, P. D. Wood and R. W. Redmond, J. Am. Chem. Soc. 1996, 118, 2366-2373; b) P. Miro, V. Lhiaubet-Vallet, M. L. Marin and M. A. Miranda, Chem. Eur. J. 2015, 21, 17051-17056.

[14] a) S. Encinas, N. Belmadoui, M. J. Climent, S. Gil and M. A. Miranda, Chem. Res. Toxicol. 2004, 17, 857-862; b) J. Trzcionka, V. Lhiaubet-Vallet, C. Paris, N. Belmadoui, M. J. Climent and M. A. Miranda, ChemBioChem 2007, 8, 402-407; c) A. Joseph, G. Prakash and D. E. Falvey, J. Am. Chem. Soc. 2000, 122, 11219-11225; d) X.L. Liu, J.-B. Wang, Y. Tong and Q.-H. Song, Chem. Eur. J. 2013, 19, 13216-13223.

[15] Z. Zuo, S. Yao, J. Luo, W. Wang and J. Zhang, J Photochem Photobiol B 1992, 15, 215-222.

[16] P. Miro, I. Vaya, G. Sastre, M. C. Jimenez, M. L. Marin and M. A. Miranda, Chem. Commun. 2016, 52, 713-716.

[17] N. J. Turro, V. Ramamurthy and J. C. Scaiano, Modern Molecular Photochemistry of Organic Molecules, University Science Books, New York, N.Y., 2010.

\section{Entry for the Table of Contents}

\section{FULL PAPER}

Spectroscopic evidence supporting formation of thymine triplet $\left({ }^{3} \mathrm{Thy}{ }^{*}\right)$ upon benzophenone (BP) photosensitization is provided in two new systems, in which BP and Thy are covalently linked to both ends of a rigid bile acid skeleton, at non-bonding distance. Thus, ${ }^{3}$ Thy ${ }^{*}$ is generated by through-bond triplet-triplet energy transfer from ${ }^{3} \mathrm{BP}^{*}$.

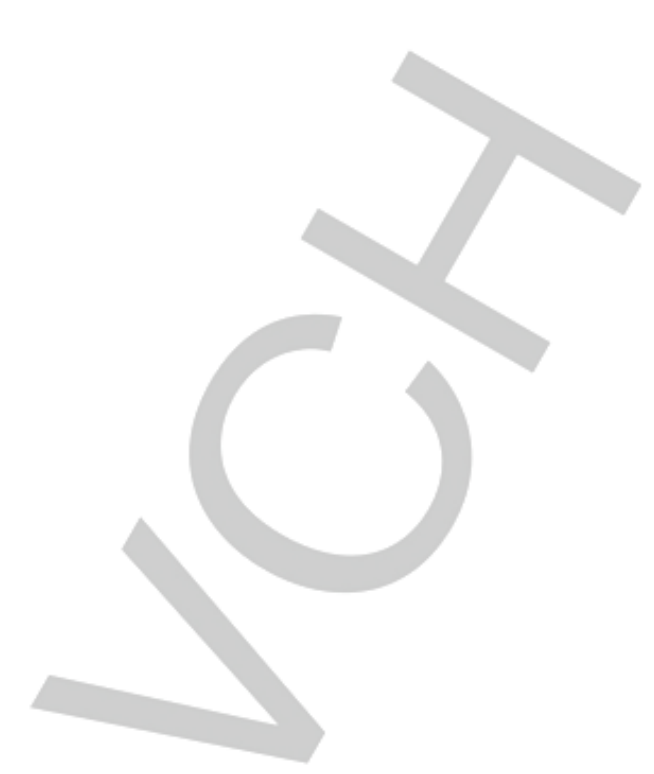

\section{1} (a) 